Annals of Plant Sciences

\title{
A new record for Valsad district, Gujarat: Salmalia insigne (Wall.) Schott \& Endl.
}

Dilipkumar D. Patel ${ }^{1}$ and Hiteshkumar A. Solanki ${ }^{*}$

1B.K.M. Science College, Valsad, Gujarat, India.

${ }^{2}$ Botany Department, School of Sciences, Gujarat University, Navrangpura, Ahmedabad, Gujarat, India.

Received: 1/16/2018; Accepted: 1/28/2018

\begin{abstract}
The present paper deals with indigenous taxa of Angiosperm belonging to family Bombacaceae. It is reported as an addition to the flora of Valsad District and a new record from wild areas of the Valsad. The paper envisages citation, detailed, description, flowering and fruiting time, followed by ecological notes along with photographs and longitudinal and latitudinal and height of the area is also provided \& mention.
\end{abstract}

Keywords: Salmalia insigne Wall.Pl. As. Rar.Kunth. New record, Gujarat

\section{Introduction}

During botanical exploration of Dharampur and Kaparada, Valsad District, Gujarat. The author has collected some specimen of. Salmalia insigne (Wall.) Schott \& Endl. It belongs to family Malvaceae (APG-3). It's locally known as "Shimlo" in Gujarat. It is commonly known as Red Silk Cotton tree, Shalmali, Simal. This is the first record for Valsad District. Earlier it is not recorded from wild forest area from Valsad (Shah, 1978) (Cooke, 1908), (Inamdar, 1968), (Reddy, 1987), (Vora, 1980). Herbarium specimen is submitted to Department of Botany, B.K.M. Science College, Valsad, Gujarat, India.

Salmalia insigne (Wall.) Schott \& Endl. Melet.35. 1832.

Synonym: Bombax insigne Wall.Pl.As. Rar. Kunth. 1:71. t.79, 80. 1830 .

Moderate sized, deciduous trees. Leaves digitate; leaflet 7-9, obovate, $10-12 \mathrm{~cm}$ long, acuminate, tapering at base, glabrous; petioles $10-15 \mathrm{~cm}$ long; petiolates $5-8 \mathrm{~mm}$ long. Flowers $8-10 \mathrm{~cm}$ across; Pedicel stout, jointed near the apex. Calyx urceolatecampanulate, 2-3 cm long, truncate or 2- lobed, glabrous outside, silky within. Corolla pinkish red; petals oblong, 10-12 cm long, tomentose; stigma 5 lobed. Capsules oblong, woody. $15-20 \mathrm{~cm}$ long, glabrous. Seeds ovoid. Embedded in silky cotton.

Flowers \& Fruits: December- March.

GPS: Latitude 20.34141, Longitude 73.24444, Height (Sea Level) 341 meter, feet.

Speciman no: $\mathrm{DH}-1050$

\section{Distribution: Kaparada, Chavsala}

Ecology: Tree attracts most of birds during flowering and fruiting season. Birds are depended on fruits of tree during fruiting time. In kaprada region there are only 17 individuals are observed.

Nomenclatural note: Typication of Bombax L. (1753) by SCHOTT and ENDLICHER (1832) who reserved the name for the American element, of $B$. Ceiba L. = B. ceiba L. sensu strict, and created a new generic name Salmalia for the Asiatic element of $B$. malabaricum DC. $(1824)=$ Salmalia malabarica DC. (1832). This name is also listed in The International Plants Names Index Id: 563331-1 Version: 1.4 checked on 28/03/2017 at $3.34 \mathrm{pm}$ (http://www.ipni.org/ipni/idPlantNameSearch.do;j sessionid=291EE163A5C5A32DF8292513470D17 E4?id $=563331$ -

1 \&back page $=$ \&show history $=$ true $)$

Type for bombax: "Moul-elavou" in Rheede, Hort. Malab., 3: 61, t. 52, 1682

Schott \& Endlicher, et al., named the Indian element as Salmalia based on Roxburgh's specimen of B. heptaphylla (Specimen no. K000357884) from India. (Specimen No. K000357884) in Kew. Roxburgh's specimen at the Royal Botanical Garden, Kew, Herbarium Number No. K000357884 can be designated as the lectotype for salmalia.

\section{Acknowledgement}

Authors are thankful to Mr. Rupesh Maurya, Research scholar, Gujarat University, for help in manuscript.

\footnotetext{
*Corresponding Author:

Dr. Hiteshkumar A. Solanki,

Professor, Botany Department,

School of Sciences, Gujarat University,

Navrangpura, Ahmedabad, Gujarat, India.

E-mail: hasolanki@gujaratuniversity.ac.in 

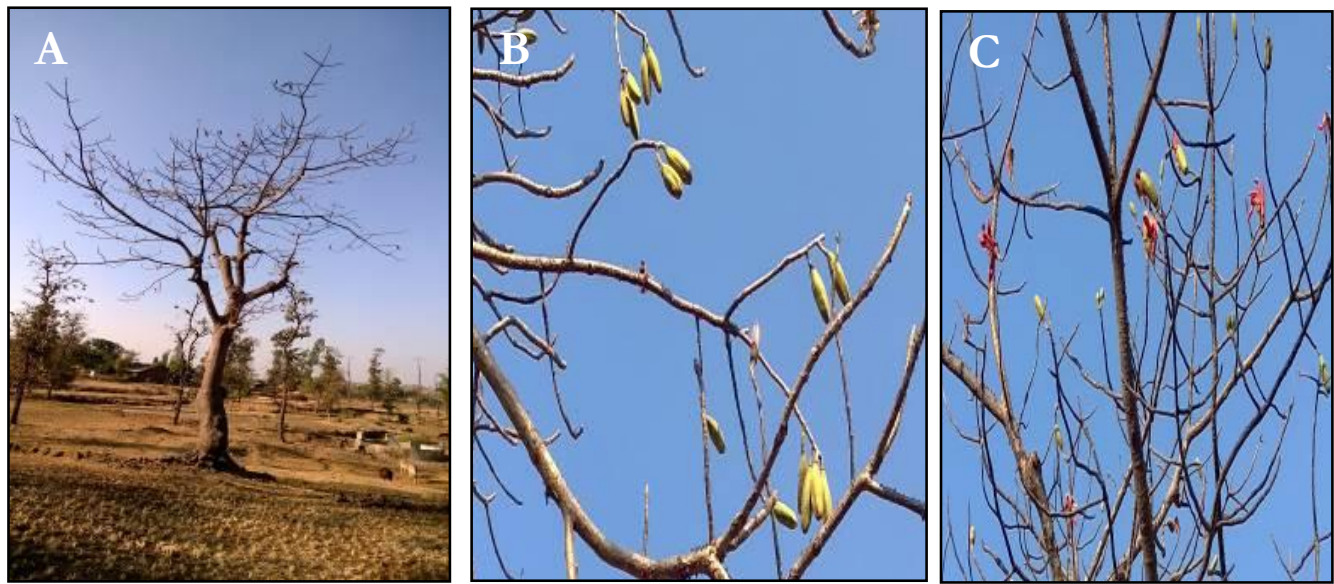

Photo plate: A: habit of tree, B: Fruits, C: Flowers

\section{References}

1. Cooke T. (1908) Flora of Presidency of Bombay. Vol I, II and III, Botanical Survey of India, Calcutta, Reprint 1958.

2. Furtado, C. X. (1938) Botanic Gardens Bulletin S S. Vol. X, Singapore, pp 173 - 181).

3. Inamdar J.A. (1968) A Prelimnary Survey of the flora of Dharampur forest in Gujarat. Bull.Bot. Surv. India, 10: 126- 132.
4. Reddy, A.S. (1987) Flora of Dharampur Forest Part 1-\& 2. Ph.D. thesis, Department of Biosciences, S.P. University, VallabhVidyanagar, Gujarat-India.

5. Shah, G.L. (1978) Flora of Gujarat State. Part I \& II Sardar Patel University, Vallabh-Vidyanagar. 1074.

6. Vora H.M. (1980) A contribution to the flora of Dharampur, Kaparada and Nanapondha ranges. Ph.D. Thesis S.G. Univ. Surat.

\section{Cite this article as:}

Dilipkumar D. Patel and Hiteshkumar A. Solanki. A new record for Valsad district, Gujarat: Salmalia insigne (Wall.) Schott \& Endl. Annals of Plant Sciences 7.2 (2018) pp. 2067-2068.

do $\mathrm{http} / / /$ dx.doi.org/10.21746/aps.2018.7.2.14

Source of support: Nil

Conflict of interest: Nil 